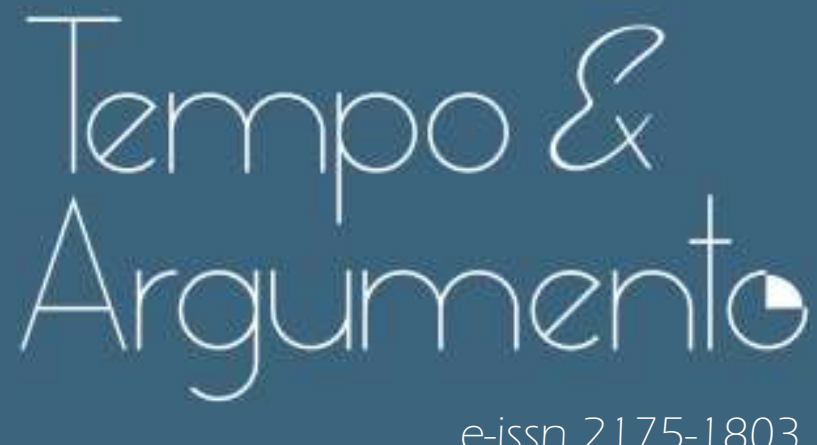

e-issn 2175-1803

Duas historiadoras e dois historiadores: o passado disciplinar romântico da historiografia brasileira nos anos 1970

- Diego José Fernandes Freire

Doutor em História pela Universidade Federal do Rio Grande do Sul (UFRGS).

Professor na Secretaria de Educação e Cultura do Estado do Rio Grande do

Norte (SEEC-RN) e na Universidade Potiguar (UNP).

Natal, RN - BRASIL

lattes.cnpq.br/7824839450030326

dieg05739@gmail.com

(D) orcid.org/0000-0001-7651-5164

Para citar este ensaio:

FREIRE, Diego José Fernandes. Duas historiadoras e dois historiadores: o passado disciplinar romântico da historiografia brasileira nos anos 1970. Tempo e Argumento, Florianópolis, v. 13, n. 34, e0501, set./dez. 2021. Ensaio.

do)

http://dx.doi.org/10.5965/2175180313342021e0501

Recebido: 10/03/2021

Aprovado: 30/10/2021 


\title{
Duas historiadoras e dois historiadores: o passado disciplinar romântico da historiografia brasileira nos anos 1970
}

\begin{abstract}
Resumo
Objetiva-se analisar a construção de um passado disciplinar arquitetado por duas historiadoras da Universidade de São Paulo, Maria Odila Leite da Silva Dias e Maria de Lourdes Monaco Janotti. No início dos anos 1970, as duas acadêmicas escreveram suas teses de doutorado nas quais mobilizaram um passado oitocentista para temporalizar a historiografia brasileira, de modo que tais trabalhos serão aqui tomados como fontes de investigação. Como ocorreu essa temporalização pretérita? Partindo desta questão e analisando em conjunto aquelas duas produções, discute-se uma nacionalização e uma disciplinarização do passado da historiografia brasileira, destacando algumas questões de gênero relacionadas não só a estes dois pontos, como também no que toca a trajetória profissional das historiadoras.
\end{abstract}

Palavras-chave: historiografia brasileira; anos 1970; passado disciplinar.

\section{Two historian women and two historian men: the romantic disciplinary pas to f the Brazilian historiography in the 1970s}

\begin{abstract}
Theobjective of this paper is to analyze the construction of a past drawn by two female historians from São Paulo University, Maria Odila Leite da Silva Dias and Maria de Lourdes Monaco Janotti. In the early 1970's, both scholars wrote their doctoral thesis in which they took a past from the 19th century to temporalize the brazilian historiography, so that such works are taken as sources of investigation in this paper. How this past temporalization happened? Starting from this question and analyzing together those two productions, a nationalization and disciplinarization of the past of Brazilian historiography is discussed, highlighting some gender issues related not only to these points, but also about to the professional trajectory of historians.
\end{abstract}

Keywords: Brazilian historiography; 1970's; disciplinary past. 
Duas historiadoras e dois historiadores: o passado disciplinar romântico da historiografia brasileira nos anos 1970

Diego José Fernandes Freire

As historiadoras universitárias

Na virada dos anos 1960 para 1970, quando o país mergulhava de vez na utopia autoritária do regime ditatorial instalado em 1964 (FICO, 2004, p. 33), duas historiadoras ingressaram na pós-graduação em história da Universidade de São Paulo (USP). A Ditadura Militar abria para a jovem classe média universitária, sobretudo aquela residente na região sudeste do Brasil, oportunidades de aprimoramento profissional, com o intuito de desenvolver o país, alçando-o ao posto de nação desenvolvida, ou - mais pessimista - em desenvolvimento. Em 1966, Maria Odila Leite da Silva Dias iniciava seu curso de doutoramento, recebendo dois anos mais tarde a companhia de Maria de Lourdes Monaco Janotti'. Produto dessa experiência de pós-graduação, ainda sob o chamado "antigo regime", duas importantes teses vieram à baila.

Em 1971, Maria de Lourdes Janotti, após defesa perante uma banca de professores, apresentou o trabalho João Francisco Lisboa: contribuição para o estudo da historiografia brasileira. Seis anos depois, o mesmo ganhou espaço no mercado editorial, com um título ligeiramente modificado: João Francisco Lisboa: jornalista e historiador. Situação semelhante aconteceu com Maria Odila Dias, que após defender, em 1972, sua tese denominada Robert Southey, historiador do Brasil - o fardo do homem branco na Inglaterra Pré-Vitoriana e a formação da nacionalidade brasileira, lançou-a em formato de livro, dois anos depois, com o título alterado para O fardo do homem branco: Southey, historiador do Brasil. Esta publicação veio sob o selo prestigioso da coleção

\footnotetext{
'As informações a respeito da trajetória das autoras (graduação, mestrado, doutorado, docência etc.) foram retiradas de duas fontes: a primeira da plataforma lattes e a outra de um currículo encontrado no Centro de Apoio a Pesquisa Histórica Sergio Buarque de Holanda (CAPH FFLCH/USP). Quando o cruzamento de tais documentos gerou incongruência, o que aconteceu algumas vezes, reportou-se a outras fontes, as quais serão referenciadas no decorrer do texto. A primeira fonte citada pode ser acessada facilmente na plataforma lattes.

2 O dito "antigo regime" de pós-graduação foi um ordenamento institucional, vigente na USP entre os anos de 1965-1973, o qual visava normatizar os primeiros cursos de mestrado e doutorado da referida instituição. Dentre as principais exigências, constavam-se: créditos disciplinares, atividades de pesquisa, orientação acadêmica por parte de um professor catedrático ou livredocente e defesa de uma monografia perante uma banca examinadora. Após a reforma universitária de 1968 que pôs fim ao regime de cátedras na Universidade brasileira, instituindo os departamentos como instância privilegiada da estrutura curricular e administrativa, a estrutura atual de pós-graduação ocupou o seu lugar. Mais informações sobre o "antigo regime" de pós-graduação podem ser encontradas em Roiz e Santos (2012) e acerca da Reforma Universitária de 1968, ver Motta (2014).
} 
brasiliana, número $344^{3}$. Com tais trabalhos, as historiadoras realizaram as primeiras pesquisas de fôlego sobre a historiografia brasileira em um contexto universitário de produção.

Além disso, elas percorreram uma trajetória acadêmica bastante semelhante (razão pela qual o corrente cruzamento está sendo feito). Ambas frequentaram as aulas do curso de história no momento em que sua autonomia curricular em relação à área de geografia já tinha ocorrido, desde 1956: Maria de Lourdes Janotti colou grau em 1959, recebendo tanto o título de licenciada como de bacharel, ao passo que Maria Odila Dias obteve as mesmas titulações no ano de 1961. A conclusão da graduação ocorreu em um período de três anos, de modo que Janotti e Dias não se formaram mais em nenhum outro curso superior.

A graduação em história que elas encontraram, na segunda metade dos anos 1950, era ainda um curso majoritariamente feminino, composto mais por mulheres do que por homens, do ponto de vista do corpo discente. A orientação para o magistério no Ensino Básico era o horizonte privilegiado das graduações na Faculdade de Filosofia da USP, o que ajuda a explicar aquele predomínio de gênero: procurava-se formar profissionais para atuarem na educação escolar. Diogo da Silva Roiz e Jonas Rafael dos Santos, por outro lado, apontaram que, "embora os formandos fossem na sua maioria mulheres, a situação se invertia quando se tratava de observar os indivíduos que exerciam atividades de pesquisa” (ROIZ \& SANTOS, 2012, p. 179). Até o momento de estabelecimento da pós-graduação na USP, no início dos anos 1960, atividades de pesquisa eram majoritariamente realizadas pelos catedráticos, os quais recrutavam discentes em sua maioria homens - para auxiliarem em suas investigações.

Observando o corpo docente de história da instituição paulista em fins do ano de 1970, pode-se ainda observar o predomínio do gênero masculino. Dos 46 docentes, apenas 17 pertenciam ao sexo feminino, perfazendo uma tímida porcentagem de 36\%. Entre as professoras, nenhuma delas era catedrática, nem

\footnotetext{
${ }^{3}$ As bancas de defesa de doutorado de Maria de Lourdes Janotti e de Maria Odila Dias contaram com os seguintes nomes, respectivamente: Eduardo de Oliveira França (Presidente), José Honório Rodrigues, Sônia Aparecida Siqueira, Antônio Candido de Mello e Souza e Carlos Guilherme Mota; Maria Thereza Shorer Petrone (presidenta), Odilon Nogueira de Matos, Celso Laffer, Antônio Candido de Mello e Souza e Sergio Buarque de Holanda.
} 
tampouco livre-docente, dividindo-se entre os postos de assistente-docente (6) e auxiliar-docente (11), ou seja, as mulheres ocupavam as carreiras iniciais do magistério superior do curso de história da USP (REVISTA DE HISTÓRIA,1971, p. 269-270) $)^{4}$ o que as colocava em uma situação de pouco prestígio na hierarquia docente, dificultando uma maior e efetiva igualdade de gênero.

Analisando as teses de doutorado defendidas entre 1967 e 1973 (momento de conclusão das teses durante o "antigo regime” de pós-graduação), pode-se expor a seguinte quantificação, percebendo a presença feminina na pesquisa historiográfica uspiana:

Quadro 01: Teses de doutorado segundo o gênero defendidas no "antigo regime" de Pós-graduação (1967-1973)

\begin{tabular}{|l|l|l|l|}
\hline Período & Autoria feminina & Autoria masculina & Total \\
\hline 1967 & 0 & 03 & 3 \\
\hline 1968 & 02 & 02 & 4 \\
\hline 1969 & 03 & 02 & 5 \\
\hline 1970 & 02 & 05 & 7 \\
\hline 1971 & 03 & 07 & 10 \\
\hline 1972 & 06 & 09 & 15 \\
\hline 1973 & 13 & 18 & 31 \\
\hline $1967-1973$ & 29 & 46 & 75 \\
\hline
\end{tabular}

Fonte: REVISTA DE HISTÓRIA, 1974, p. 821-85

Todavia, no total dos doutoramentos concluídos durante o "antigo regime", as historiadoras universitárias compareceram com 38,6\%, número inferior a metade da produção historiográfica da USP, ao passo que os historiadores universitários foram responsáveis por 61,3\%. Tal porcentagem corrobora o caráter generificado no âmbito da pós-graduação uspiana em história, instância por excelência da pesquisa historiográfica universitária.

\footnotetext{
${ }^{4}$ Levaram-se em conta os professores efetivos e os contratados.

5 Trata-se de um levantamento das teses defendidas no departamento de história da USP entre 1939-1974, elaborada por Maria Regina da Cunha Rodrigues Simões de Paula (REVISTA DE HISTÓRIA, 1974, p. 821-857). Optou-se pelas teses e não pelas dissertações em razão das primeiras representarem o grosso da pesquisa de pós-graduação em história da USP, afinal inexistia o pré-requisito de um nível para o outro.
} 
Logo, Maria de Lourdes Janotti e Maria Odila Dias representaram um número pequeno e seleto de mulheres que conseguiram ingressar e concluir o doutoramento, em meio a tantos homens, muito dos quais professores catedráticos. Após suas teses, ambas passaram a atuar na pós-graduação como docentes. Desde 1965 e 1966, Janotti e Dias, respectivamente, trabalhavam na USP como professoras-assistentes. A primeira assistiu Emilia Viotti da Costa, na disciplina de Teoria e Metodologia da História, ao passo que a segunda trabalhou com Sergio Buarque de Holanda na cadeira de História da Civilização Brasileira. Porém, toda essa trajetória acadêmica e profissional não foi palmilhada sem dificuldades. Isso porque a condição de historiadora universitária era vivenciada em um universo carregado de tensões e conflitos.

Para elas, a produção intelectual e a atuação profissional não as blindavam de injúrias e outras violências decorrentes do gênero. A despeito dos postos privilegiados que poderiam vir a ocupar - assistentes de docentes ilustres (no caso de Maria de Lourdes Janotti e de Maria Odila Dias) e pós-graduandas -, obtidos não sem disputas e questionamentos, elas sofriam violência simbólica em razão do gênero feminino que representavam (BOURDIEU, 2005; BUTLER, 1987). Como apontou Bonnie Smith, no meio universitário, quando se trata de personagens femininas, nem sempre os marcadores do mérito acadêmico se corporificam, ao ponto de estruturar relações de igualdade entre os pares (SMITH, 2003). Na ordem do saber disciplinar, tal qual estruturado pelo espaço universitário, outras ordens de poder e de saber se perfilam, desenhando uma geografia complexa para as relações sociais que ali têm lugar.

Se Maria de Lourdes Janotti nada explicitou deste ponto de vista - o que não deixa de ser significativo -, sua colega de profissão e de universidade, ainda que laconicamente, assegurou em entrevista que "havia também um certo machismo. Preferiam professores homens" (DIAS, 2002, p. 188). No entanto, outras historiadoras universitárias da USP, asseguradas pelo anonimato, confidenciaram a Carmem Silva da Fonseca Liblik, autora de uma importante tese sobre o assunto, o quanto a situação das historiadoras pesquisadoras era sofrível, em razão de estruturas de discriminação e opressão de gênero, existentes no espaço universitário: 
Eu entrei numa época em que as cátedras não existiam mais. Mas ainda se faziam contratações por indicação. Então você era indicado por um grupo. E havia um velho catedrático que depois da Reforma Universitária passou a se chamar professor titular, que dizia que na antiga cátedra dele, mulher não entrava. Para ele, as mulheres causavam muitos problemas. Primeiro elas tinham filhos, e depois gostavam sempre de fofocar, que criavam problemas e intrigas. De todo modo, eu penso que os velhos catedráticos olhavam as mulheres, digamos, como se elas não tinham que estar lá. O Departamento tinha muitas mulheres e eles olhavam com uma certa condescendência. Mas o poder efetivo do Departamento estava nas mãos deles, dos homens (LIBLIK, 2017, p. 225-226)

No período anterior à Reforma universitária de 1968, tudo indica que a situação era pior para as mulheres que ousavam assumir uma atitude de pesquisadora, como foi o caso de Maria de Lourdes Janotti e de Maria Odila Dias. Marilena Chauí, intelectual universitária da USP cuja trajetória na filosofia encontra várias semelhanças com as das historiadoras em tela (concluiu a graduação em 1965, mestrado em 1967 e doutorado em 1971), confidenciou que

Em 1967, ingressei como professora do Departamento de Filosofia da Universidade de São Paulo, após defender dissertação de mestrado. Foi um ingresso inesperado para mim e, pelo que me contaram tempos depois, foi controvertido para outros. Inesperado porque eu tinha o intuito de ser professora no ensino secundário, por estar convencida da importância formadora da filosofia. Controvertido porque o professor que dirigia 0 departamento não via com bons olhos a contratação de mulheres para a universidade, sua maior objeção (compartilhada por vários professores) era a maternidade. Tempos mais tarde, eu soube que um dos professores, favorável ao meu ingresso, galhofeiramente propusera ao departamento minha esterilização, já que minha fertilidade causava tanto mal-estar. (SECOM UNB, 2018)

Emília Viotti, também em entrevista concedida em 1999 a uma ex-aluna que passou a trabalhar com ela na disciplina de Teoria e Metodologia da História, Sylvia Basseto, evocou uma triste situação na qual suas escolhas pessoais ligadas à sua performance feminina não foram respeitadas:

O incidente que levou a essa decisão teve a ver com o nascimento de uma segunda filha. Quando anunciei que precisaria um ajustamento do horário para amamentar, o professor Oliveira França me fez um discurso dizendo que se eu pretendia ter filhos nunca seria uma intelectual. Furiosa, disse a ele que, se pretendia cercear minha vida pessoal, eu preferia me demitir. Foi o que fiz. 
No dia seguinte apresentei a demissão do cargo que tanto almejara. Comecei então a dar aulas num curso de Introdução aos Estudos Históricos recém-criado no Departamento e recebi, depois de algum tempo, minha indicação para a nova posição. Encerrara um capítulo importante de minha vida para começar um novo. (BASSETO, 1999, p. 21)

Assim, antes ou depois da Reforma Universitária de 1968, entre os intelectuais universitários, as historiadoras representavam um grupo diferenciado, a sofrer violências e coações peculiares, ligadas à condição feminina do gênero. Por mais que estivessem no interior da mesma instituição de saber, elas possuíam traços e atuações que eram ignorados pelos seus pares masculinos. A condição feminina gerava determinados constrangimentos que, explicitados ou silenciados, moldavam um perfil intelectual e profissional generificado, dentro de um mesmo indivíduo epistêmico (BOURDIEU, 2011, p. 4463) ${ }^{6}$. Foi nessa condição ambivalente e complexa que Maria de Lourdes Janotti e Maria Odila Dias escreveram suas teses de doutoramento, enfrentando problemas de gênero que se imiscuíam com questões relativas à própria disciplina?. Nesse passo, o passado disciplinar (KELLEY, 1997), isto é, a temporalidade pretérita mobilizada para situar historicamente o conhecimento histórico tal qual produzido no país, emergiu como uma questão proeminente.

Como se verá, no início da década de 1970, Janotti e Dias contribuíram com o gesto de historicização da disciplina histórica no Brasil. Ao contrário do que certa memória disciplinar aponta, destacando apenas o nome de José Honório Rodrigues como o único autor a se preocupar com a história da historiografia brasileira antes dos anos 1980 (ARAÚJO,2012; GUIMARÃES, 2005), tal gesto contou com a participação de importantes mulheres, jovens intelectuais

\footnotetext{
${ }^{6}$ Mais informações sobre a condição das intelectuais universitárias na USP, de uma maneira geral, consultar a importante obra de Eva A. Blay e Alice Beatriz Lang, que não só examina o referido objeto como traz o depoimento de várias mulheres, algumas das quais historiadoras (BLAY\& LANG, 2004).

Nos últimos anos, diversas historiadoras do Brasil estão fazendo um importante esforço de analisar a história da historiografia brasileira sob o enfoque das relações de gênero. Além do trabalho de Carmen Silvia da Fonseca Liblik, destaca-se também o artigo de Maria da Glória de Oliveira, denominado os sons do silêncio: interpelações feministas decoloniais à História da historiografia (OLIVEIRA, 2018), bem como a tese de Aryana Costa (COSTA, 2018). Esforço digno de nota também diz respeito à criação da HUMANAS: pesquisadoras em rede, a qual tem não só reunido várias historiadoras como tem disponibilizado todo um material de produção e divulgação do conhecimento histórico nos quais a discussão de gênero é um ponto central.
} 
que, em seus processos formativos, dirigiram um olhar histórico para o saber que aprendiam e praticavam. Além de Maria de Lourdes Janotti e Maria Odila Dias, as quais receberão maior destaque nestas linhas em razão do pioneirismo e do fôlego de suas pesquisas, poder-se-iam citar as figuras de Raquel Glezer, Katia Abud, Emilia Viotti da Costa, Alice Canabrava e Cecília Westphalen como historiadoras universitárias que em algum momento voltaram a análise sobre si mesmas, em termos disciplinares (ERBERELI JÚNIOR, 2019; MACHADO, 2016).

Nesse sentido, o corrente texto pretende investigar, de forma cruzada, o modo como as autoras Maria de Lourdes Janotti e Maria Odila Dias fabricaram um passado disciplinar para a historiografia brasileira a partir de suas teses de doutoramento. Mediante seus objetos de pesquisa, elas temporalizaram sua área de saber, abordando a época da história no e do Brasil durante o século XIX. Isso significa dizer que uma temporalidade oitocentista foi arquitetada e movimentada, a qual dotava de historicidade o conhecimento histórico nacional conforme praticado nos anos 1970. Assim, as questões-chave que se colocam são: de que modo tais teses produziram um passado para a historiografia brasileira? Como e por que João Francisco Lisboa (1812-1863) e Robert Southey (1774-1843) foram percebidos como historiadores do Brasil e, assim, perfilaram um dado passado disciplinar? De que maneira esse tempo ido se relacionou com o presente das autoras?

Em um primeiro momento, abordar-se-á a historicidade disciplinar oitocentista a partir de sua relação com a nação brasileira, para em seguida tratála na sua íntima vinculação com a disciplina histórica, tal qual Maria de Lourdes Janotti e Maria Odila Dias a evidenciaram. Aqui, em alguns lances, também se chamará a atenção para algumas discussões de gênero. Ao longo do texto, a metodologia caminhará por uma análise cruzada das supracitadas teses de doutorado, com base em "procedimentos relacionais" (ZIMMERMANN \& WERNER, 2003, p. 97), a exemplo do que se fez mais acima com o breve relato da trajetória profissional das historiadoras. Ao final, evidencia-se que as autoras das teses examinadas operaram no registro da disciplina, o que gerou certos condicionamentos e dadas relações entre passado e presente. 


\title{
Romantizar a história, nacionalizar o passado
}

\begin{abstract}
A historiografia não é, de modo algum, o que vem do passado até nós, mas o que parte de nós e tende a fornecer certo tipo de inteligibilidade do que recebemos ou estabelecemos como passado. (CERTEAU, 2011, p. 177-178)
\end{abstract}

Janotti e Dias pensaram seus objetos mediante uma operação de corte temporal. Tanto a obra de João Francisco Lisboa quanto a History of Brazil de Robert Southey representariam inovações, isto é, rupturas com uma tradição de estudo anterior. Logo, elas surgiriam como marcos de uma história da historiografia brasileira. Contemplando a evolução da história no Brasil, é como se a produção do letrado brasileiro e do poeta inglês emergissem como significativas, como capitais para a compreensão histórica do conhecimento investigado. Talvez tenha vindo dessa percepção inaugural o interesse das historiadoras em estudar seus respectivos objetos de pesquisa.

A autora de João Francisco Lisboa utilizou em sua tese uma tópica comum nos estudos de história da historiografia, qual seja, a distinção entre crônica e historiografia. Desde os estudos de Gustav Droysen nas décadas finais do século XIX, os de Benedetto Croce e de Edward Futer ${ }^{8}$ no início do século XX, passando pelos de Harry Barnes e George Lefebre no final da primeira metade dessa era, as chamadas "histórias gerais da historiografia ocidental" (DA SILVA, 2001, p. 5887) delimitavam uma separação entre o cronista e o historiador. O primeiro faria o registro do vivido no presente e para o presente, ao passo que ao segundo caberia a reflexão para além da simples anotação do que se viu ou se viveu. Nas palavras de Croce, tratar-se-iam "de duas atitudes diferentes: a história é a história viva, a crónica é a história morta; a história é um acto de pensamento, a crónica um acto de vontade" (CROCE, 1984, p. 281). Ecoando essa mesma discriminação, mas somando a ela as reflexões de Antonio Candido, Maria de Lourdes Janotti assinalou que João Francisco Lisboa representaria um "momento decisivo" na história da história no Brasil.

\footnotetext{
${ }^{8}$ O livro deste autor, intitulado História de la historiografia, conforme a versão espanhola do original alemão, foi inserido nas referências bibliográficas da tese.

9 A história da literatura brasileira, historicizada por Antônio Candido em fins dos anos 1950,
} 
Por mais que elementos da crônica possam ser encontrados na historiografia de João Francisco Lisboa, sua produção se inseriria em uma conjuntura nova, essencialmente diferente, já que haveria uma diferenciação radical entre a produção cronística e a historiográfica. A primeira apresentaria "denominadores comuns diferentes da historiografia", haja vista que "os cronistas, uns mais, outros menos, estavam cônscios de seus papéis. Escreviam para registrar informações úteis aos seus sucessores, quer na atividade religiosa ou civil; preocupavam-se com as nobiliarquias, corografias, e memórias de famílias ou anais de entidade" (JANOTTI, 1971, p. 14). A crônica seria um discurso utilitário, fruto de um interesse informativo imediato a respeito de algum objeto. Desse modo, apenas indiretamente serviria aos propósitos de conhecimento da realidade sobre a qual se debruçava.

Os parágrafos seguintes à citação anterior vão dando o tom da separação: “bastante diferentes os chamados 'historiadores românticos', cônscios de seu papel, eles escrevem por missão, buscam e criam as bases tradicionais do país que nasce" (JANOTTI, 1971, p. 15). Maria de Lourdes Janotti identificou inicialmente os historiadores românticos ao Brasil, à nação recém-constituída, enquanto que os cronistas representariam o período colonial, no qual a nacionalidade não estava ainda colocada. Assim, à passagem da colônia para a nação corresponderia também o movimento da crônica para a historiografia brasileira. Esta teria surgido com a nação, de maneira que "o árduo caminho que de medíocres notícias cronológicas chegou à obra de Adolfo Varnhagen, demonstra o esforço de um país para libertar-se e criar os seus padrões nacionais, e representa as inter-ligações entre o plano das realidades político-sociais e o da observação e crítica históricas" (JANOTTI, 1971, p. 14).

$\mathrm{Na}$ operação de distinção entre crônica e historiografia, a nação surge como elemento fundamental de discriminação entre uma produção e outra, muito mais do que as ambições intelectuais. Os estudos históricos seriam parte já de uma consciência nacional sobre si, evidenciando uma outra realidade histórica. Enquanto a crônica se inseriria no sistema cultural da colônia - daí o 
afã de levantar informações sobre o território e de repassá-las a outros indivíduos -, a historiografia encarnaria o rosto da nação em busca de si, de suas formas, desenhos e traços. Ali, a vontade de saber seria pragmática, interesseira, político-administrativa; aqui, ela seria autêntica, genuína, sincera, posto que ocorreria no contexto de um país independente que buscava se afirmar interna e externamente. Em uma palavra: a historiografia seria o momento de reconhecimento da nação, ocasião privilegiada em que a última se despia para a primeira.

Arrematando essa simbiótica ligação, asseverou-se:

A historiografia brasileira nasce comprometida com a independência do país, desenvolvendo-se nas lutas da Regência, (aparecimento das historias regionais) e chega a sua maturidade no século XIX com Varnhagen e a idealização do Império brasileiro como forma politica de integração. [...] O 'nascimento' da historiografia brasileira é concomitante ao nascimento do país independente e ao estuda-la nos fins do século XVIII e no século XIX, sente-se em sua evolução todas as vicissitudes da nova nação. (JANOTTI, 1971, p. 18-19)

Forte elemento da cultura nacional, a historiografia viria em decorrência da nação, estando nela inserida, quase que sem autonomia. Percorrer o passado oitocentista seria encarar, além da marcha da nação, o próprio curso da história no Brasil, através de autores e obras que ansiaram por recuperar as origens de sua nacionalidade. A história, a historiografia brasileira, seria como que um espelho da nação. Enquanto esta se erguia, a outra também começava a ganhar existência.

A nação também se colocou como um elemento decisivo na análise de Maria Odila Dias, no que diz respeito ao corte temporal que a autora viu a partir de History of Brazil. Embora a historiadora universitária não tenha operado com a distinção entre crônica e historiografia, ela enxergou em Robert Southey o primeiro historiador que aplicou um "princípio de nacionalidade"10 à história do Brasil. O poeta inglês, ao contar a história de uma colônia portuguesa, não o fez subsumindo a colônia na metrópole. Antes, teria captado pioneiramente o

\footnotetext{
10 Tal expressão aparece em diversos momentos da tese da historiadora, como que estruturando sua análise acerca de Robert Southey e sua History of Brazil.
} 
desabrochar de uma nacionalidade relativamente autônoma em relação à mãepátria. Mesmo tendo sido escrita e publicada antes de 1822, History of Brazil já anteciparia

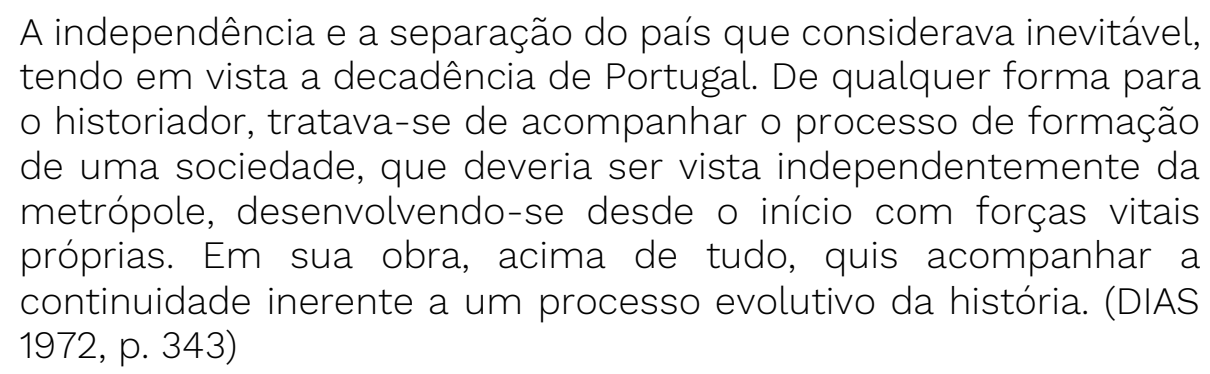

Inglês que nunca visitou o Novo Mundo, Robert Southey teria registrado não tanto a história de uma colônia presa a uma metrópole, mas sim a de uma que, progressivamente, foi afrouxando os laços coloniais, formando-se, pois, "galho tão pesado não pode permanecer por muito tempo unido a um tronco tão carcomido" (DIAS, 1972, p. 265).

Tal posicionamento, conforme Maria Odila Dias explicitou, viria da própria concepção que Robert Southey teria em relação ao processo histórico de diferentes sociedades. Este seria entendido a partir de um prisma orgânico evolutivo, no centro do qual estaria a "formação da comunidade social e do Estado-nação" (DIAS, 1972, p. 391). Romântico historicista, seguidor da tradição de Herder, o autor de History of Brazil perseguiria a formação de um ethos nacional, o germinar de um povo autêntico, consciente de si e de sua singularidade. A história seria o caminhar dos diferentes povos, já que "não se fabrica nações do dia para a noite” (DIAS, 1972, p. 118). Maria Odila Dias, assim, enfeixou a visão histórica de seu personagem principal: "tinha o conceito vitalista e orgânico do crescimento evolutivo das sociedades através dos tempos, de estágios históricos próprios e necessários a cada fase de desenvolvimento" (DIAS, 1972, p. 120).

Foi com essa visão de mundo - categoria-chave em sua tese - que Maria Odila Dias entendeu que History of Brazil foi produzida, colocando seu autor como o primeiro historiador do Brasil, como faz jus o próprio título do trabalho da historiadora. Não à toa, destacou-se na tese de doutoramento a volúpia southeyana de ser o "Heródoto da América do Sul" (DIAS, 1972, p. 40), ou seja, o 
pai fundador dos estudos históricos no Novo Mundo, tal qual o grego de Halicarnasso para o Velho Mundo - eurocentricamente. De fato, Robert Southey colocou History of Brazil como pedra angular da historiografia brasileira, base a partir da qual se edificou todo um pensamento histórico nacional. A proposta de escrever a história da colônia portuguesa como um período em que as sementes de uma nova nacionalidade - a brasileira - estavam sendo plantadas teria sido perseguida, de forma inédita, por Robert Southey, ainda no começo do século XIX, de maneira que History of Brazil "lançou os fundamentos da historiografia brasileira" (DIAS, 1972, p. 474) ${ }^{11}$.

Em vários momentos de seu trabalho, Maria Odila Dias estabeleceu vínculos peremptórios entre as ideias de Robert Southey e a historiografia brasileira, como a indicar a influência de um no outro. Além da perspectiva nacional, fundadora dos estudos históricos no Brasil, sublinhou-se a presença de visões southeyanas que teriam cravado raízes em diversos letrados brasileiros. A valorização dos jesuítas enquanto agentes da colonização, a necessidade de integrar índios e africanos na nação, a consciência e até a positivação da mestiçagem e a possibilidade de o Brasil se civilizar no futuro seriam ideias expressas por History of Brazil, e ventiladas pela instituição máxima da historiografia brasileira no século XIX, o Instituo Histórico-Geográfico Brasileiro.

Na análise em tela, a obra de Robert Southey chegou a ir além da história: "as ideias de Southey sobre perspectivas de formação de uma futura nacionalidade não divergiram muito dos portugueses e brasileiros que se empenhavam na consolidação do novo império. Viriam mesmo ao encontro dos princípios essencialmente conservadores de formação do Estado Brasileiro" (DIAS, 1972, p. 472). A historiadora posicionou o letrado inglês como uma espécie de matriz formativa dos estudos históricos no Brasil. As ideias e os posicionamentos do autor de History of Brazil encontrariam solo fértil para se reproduzir na sociedade brasileira, não tanto em razão de sua genialidade, mas sim porque expressavam uma ideologia conservadora e autoritária, na qual o Estado era o agente principal da história. A história da formação do Estado brasileiro, segundo Dias, confirmaria essa incorporação simbólico-política. Como

\footnotetext{
${ }^{11}$ Foi justamente com essa frase que a autora encerrou sua tese.
} 
a historiografia nacional se fez sob a sombra do imperador, ela igualmente acolheria e disseminaria um conservadorismo autoritário.

Em um sentido específico, intimamente relacionado à nação, Maria de Lourdes Janotti e Maria Odila Dias usaram a noção de romântico para qualificar seus sujeitos de pesquisa. João Francisco Lisboa e Robert Southey estariam ligados a um romantismo - luso-brasileiro e inglês, respectivamente em razão de buscarem em suas obras a revelação de uma nacionalidade, de um ethos nacional, materializado em costumes, tradições, valores, crenças, em uma palavra: em um povo. Daí que o letrado maranhense e o poeta inglês compartilhariam uma preocupação estilística com a história, não escrevendo apenas relatos factuais de teor político-administrativos. O povo de carne e osso, o cotidiano vivido de homens e mulheres, em seu gênio nacional, em sua nacionalidade própria, pulsaria nas histórias analisadas pelas historiadoras universitárias ${ }^{12}$.

Emilia Viotti da Costa, professora de ambas na graduação e na pósgraduação, também mobilizou nos anos 1970 o termo romântico para enfeixar a historiografia brasileira da primeira metade do Oitocentos. Segundo ela, "há que se reconhecer, primeiramente, a historiografia de tradição romântica, seja liberal, seja conservadora, que tem origem no século XIX, ligado à organização e institucionalização do país independente. É uma historiografia que corresponde à consciência histórica da sociedade essencialmente rural, senhorial e escravista" (COSTA, 1972, p. 51). O raciocínio da historiadora universitária, empreendido em 1971, é o mesmo de suas ex-alunas: associa romântico à nação, como que nacionalizando aquela categoria. Desenvolvendo a conceituação, afirma que a historiografia romântica se caracteriza "por valorizar o papel dos personagens na História e por uma noção vaga e imprecisa de povo, encarado como abstração atuante na História, de uma forma que lembra a ideia que Michelet tinha da participação do Povo na História" (COSTA, 1972, p. 52).

\footnotetext{
2 Eduardo de Oliveira França, ao registrar as atividades desenvolvidas no departamento de história da USP durante o ano de 1970, um ano antes, portanto, de Maria de Lourdes Janotti defender sua tese, registrou o trabalho desta com o seguinte título: "historiografia romântica: João Francisco Lisboa" (REVISTA DE HISTÓRIA, 1971, p. 275).
} 
Contudo, a existência de um passado disciplinar romântico da historiografia brasileira, oriunda do século XIX, não era um consenso entre os historiadores e as historiadoras. Respondendo diretamente às considerações de Emilia Viotti da Costa ${ }^{13}$, Alice Piffer Canabrava, professora de história da USP no departamento de Ciências Econômicas, optou por falar não em uma historiografia romântica, mas sim em uma "empírica ou empirista". Segundo ela, "em Varnhagen e na maior parte de seus seguidores é difícil entrever interesse quanto a 'folkways'. Parece-nos uma incoerência ver na obra desses empíricos uma caracterização abstrata da noção de povo, 'de uma forma que lembra a ideia que Michelet tinha do povo'” (CANABRAVA, 1972, p. 64). Na verdade, o período oitocentista da historiografia brasileira estaria dominado por historiadores avessos ao povo, tal qual as autoridades políticas do Segundo Reinado.

José Roberto do Amaral Lapa e Pedro Alcantara Figueira, importantes estudiosos da história no Brasil durante o decênio de 1970, preferiram analisar o passado de sua disciplina com base em categorias eminentemente políticas. Tanto um como o outro destacaram uma historiografia conservadora, oposta a uma outra liberal (LAPA, 1976, p. 20; FIGUEIRA, 1974, p. 112-172). Nesse mesmo passo mas ampliando-o, Nilo Odália, filósofo formado na USP que escreveu em 1979 uma tese sobre Francisco Adolfo de Varnhagen (1816-1878), o dito "pai da historiografia brasileira", trabalhou não só com a categoria de seus colegas universitários, como também com as noções de - historiografia - burguesa, autoritária, eurocêntrica e elitista (ODÁLIA, 1997, p. 25-107). Em Maria de Lourdes Janotti e Maria Odila Dias, todavia, a conceituação política não está de todo ausente, mas minorada por um forte entendimento cultural e historiográfico da noção de "romântico".

Se - conforme Johan Huizinga -, "o romantismo tem tantas faces quantas foram suas formas de expressão" (HUIZINGA, 2008, p. 12), o traço nacional foi apropriado pelas historiadoras universitárias como o elemento

\footnotetext{
${ }^{13} \mathrm{O}$ debate entre as duas historiadoras universitárias ocorreu em 1971 e foi travado em um evento específico, que reuniu importantes membros da comunidade historiográfica da época no Brasil: o Encontro internacional de Estudos Brasileiros, dentro do qual havia um espaço para discussões a respeito da área de história do e no Brasil. Mais informações sobre este evento em: (GONTIJO, 2017).
} 
definidor do ser romântico, justificando, pois, seu uso para caracterizar autores e movimentos historiográficos. Micheal Lowy e Robert Sayre também assinalaram a verve nacional como importante componente da visão de mundo romântica, em oposição ao universalismo iluminista que se hegemonizou a partir do século XVIII. Nesse sentido, os autores colocaram o alemão Johan Herder como aquele que inaugurou a perspectiva particularizante na filosofia romântica, em fins daquele século, tão bem expressa na visão segundo a qual "cada forma de perfeição humana é, num certo sentido, nacional e temporalizada, e, considerada de forma mais especifica, individual" (LOWY \& SAYRE, 1995, p. 43). Na comunidade humana tão enaltecida pela tradição do Esclarecimento, haveria individualidades, de maneira que as nações, os diferentes povos, comporiam partes significativas desse conjunto maior, tido como a humanidade.

Romântico parece funcionar como o nó a enfeixar as classes de história, historiografia e nacionalidade, unindo esses três termos de forma coesa. Categoria agrimensora, ela permitiria captar a consciência da nação, de uma comunidade nacional, por parte daqueles letrados que escreviam a respeito de um suposto passado comum. Contra o universalismo da Ilustração, ela seria a marca de uma especificidade histórica, o lampejo de um povo que se descobre como singular, possuidor de uma história própria que seria preciso revelar, contando-a para a posteridade. Logo, nada teria de pejorativo, como de operacional, a sinalizar para uma sociedade que se firmava enquanto nação específica. Através dela, seria possível contar uma história da história no Brasil, tendo a condição nacional como referente principal, compasso a orquestrar o desenvolvimento historiográfico. Tratar-se-ia, assim, de uma categoria históricoreflexiva (LIMA, 2007).

Maria de Lourdes Janotti e Maria Odila Dias se apropriaram da proposta de Antonio Candido de escrever uma história da literatura no desejo que esta tinha de ser nacional. Uma historiografia brasileira, assim como sua congênere literária, surgiria quando houvesse "o nacional" a ser buscado, desejado e descrito (CANDIDO, 1981). No caso delas, a apropriação resultou em um esforço de escrever uma história da historiografia na qual se perseguiria o desabrochar de uma consciência nacional, de um pensamento histórico brasileiro. O autor de 
Formação da literatura brasileira, em verdade, foi mais do que uma referência intelectual de pesquisa, constituindo-se como um interlocutor privilegiado, como demonstra sua presença nas bancas de defesa de tese de Dias e de Janotti. Ambas as historiadoras, em razão desse diálogo, manifestaram gratidão ao companheiro de instituição ${ }^{14}$.

Historicizando a historiografia brasileira, tinha-se a oportunidade de contemplar, em perspectiva temporal, um duplo fenômeno: a produção da história no Brasil e sobre o Brasil. A historiografia era pensada como uma produção intelectual, como um conhecimento específico, a história, mas uma produção voltada para um objeto preciso, o Brasil, a nação. Outrossim, examinando as teses João Francisco Lisboa e Robert Southey, percebe-se que a categoria "historiografia brasileira" carregava tanto uma marca epistemológica quanto identitária: historiografia e nação, respectivamente, como se uma procurasse a outra, instintivamente.

Com essa junção, refletir sobre a história era igualmente pensar sobre o país no qual a historiografia tinha lugar, o que explica as imbricações entre história do e no Brasil. Na feliz expressão de Jacques Rancière, havia uma "política do saber", que transformava o pensamento sobre um conhecimento em uma visada sobre a própria nação (RANCIĖRE 1995, p. 210), objeto desse mesmo saber. Daí se discutir, dentro de uma proposta de história da historiografia brasileira, a história no e do Brasil. Em suma: a historiografia não se apartava da nação; antes a enformava na mesma medida em que era por ela enformada. Uma intensa dialética entre nação e historiografia marcou as teses de doutorado de Maria de Lourdes Janotti e de Maria Odila Dias, no momento em que elas analisam seus objetos e constroem um passado disciplinar para a historiografia brasileira.

Se a preocupação com a nação era uma tônica reluzente dos anos 19601970, vide o nacionalismo autoritário da Ditadura Militar (REIS, 2005; BURMESTER, 1998), no caso da pesquisa de Maria Odila Dias a questão nacional se radicalizava ainda mais. A historiadora universitária teve sua pesquisa atrelada à cadeira de

\footnotetext{
${ }^{14}$ Gratidão essa expressa no discurso de outorga do título de professora emérita da USP. Ainda nos agradecimentos do Livro O fardo do homem branco, Maria Odila Dias homenageou Antonio Candido e sua esposa, "a Dona Guilda", por "estimularem desde o início minha carreira universitária” (DIAS, 1974, s/p).
} 
História da Civilização Brasileira, a qual, na estrutura institucional de pósgraduação em história da USP, funcionava como uma instância legal balizadora das reflexões. Uma pesquisa ligada ao Medievo, ou à Antiguidade dita clássica, não poderia ser realizada na referida cadeira. Outrossim, a própria orientação formal da tese atuava com um elemento de enquadramento da pesquisa, por mais flexível e frouxo que fosse à época. A pós-graduação uspiana da época anterior a 1968 exigia uma relação direta entre a temática da tese e os conteúdos curriculares da cadeira (ROIZ, 2012; PATO, 2014).

Outro elemento condicionador da pesquisa consistia nos membros da banca de defesa do doutoramento - os destinatários de todo e qualquer trabalho acadêmico, e que muitas vezes funcionam como uma "polícia do discurso", conforme as inspirações foucaultianas lembradas por Michel de Certeau (DE CERTEAU, 1982). Aqui, todos eles dialogavam com a história do Brasil, com destaque para os nomes de Antonio Candido e Sergio Buarque de Holanda, os quais incursionaram por tal área ao longo de toda sua obra. Não raro, aos dois era atribuído o epíteto de "intérpretes do Brasil". Constrangida por tais agentes institucionais, pensar a nação era mesmo algo incontornável, especialmente para o trabalho de Maria Odila.

Dessa forma, o passado disciplinar da historiografia brasileira se confundiria com o passado nacional, romanticamente. Um teria nascido com o outro, de forma siamesa. Espelho da nação, a historiografia brasileira teria seu tempo pretérito iluminado pela própria origem nacional. As teses produziram como que uma nacionalização do passado da historiografia brasileira, vinculando história e nação. Nesse sentido, o trabalho de Maria Odila Dias é por deveras significativo, já que, antes mesmo da pátria, se poderia entrever o rosto nacional, em relance, através de um "princípio da nacionalidade": Robert Southey, do - e enquanto - estrangeiro, com um olhar de fora, teria contado (profetizado?) a história da nação que ainda viria, pavimentando o solo sobre o qual a história no e do Brasil se ergueria. No entanto, Dias e Janotti avalizaram seus sujeitos para além de uma discussão nacional, adensando ainda mais o passado disciplinar da historiografia brasileira. 


\section{Romantizando dois historiadores, disciplinando a história}

A História, como o masculino, como o seu poder, como o tempo, seria o que permanece (ALBUQUERQUE JR, 2007, p. 49)

João Francisco Lisboa e Robert Southey representariam o passado da historiografia brasileira não somente por encarnarem uma consciência nacional, por terem escrito obras históricas a respeito do Brasil. Para além da questão nacional, haveria nos dois letrados um métier que os habilitaria a adentrarem pelos propileus da historiografia brasileira. Eles foram considerados parte importante do passado disciplinar desta área de saber porque encarnariam uma persona de historiador, praticando um ofício valorado como historiográfico, conforme se verá. Ao longo das teses de Maria de Lourdes Janotti e de Maria Odila Dias, em inúmeras passagens, os respectivos personagens foram qualificados como "historiador". Essa figura de saber, presente já no título originário da tese de Maria Odila Dias, apareceu quando da publicação em livro do trabalho de Maria de Lourdes Janotti, em 1977: João Francisco Lisboa: jornalista e historiador.

A qualificação de "historiador", como vem demonstrando os estudos de Herman Paul, não é algo natural, espontâneo e anárquico. No caso das duas teses em apreço, obedeceu a um entendimento do regime disciplinar consagrado no Oitocentos ocidental, no qual a crítica documental e a erudição funcionariam como os elementos decisivos da história como ciência. Sobre isso, as palavras a seguir são exemplares:

Ao 'eu vi' que fundamentara a escrita da história em suas formas clássicas, corresponde agora o 'eu li' da consulta aos arquivos e acervos, que para isso deveriam estar disponível, mas, sobretudo, em condições de legibilidade. [...] Tratava-se de submeter a documentação escrita aos procedimentos da crítica erudita visando estabelecer a autenticidade e a fidedignidade dos documentos em questão. Somente quando vencida essa etapa poder-se-ia estabelecer os fatos do passado como verdadeiros e, por isso mesmo, base confiável para uma escrita da história. [...] Somente após serem submetidos a crítica rigorosa, poderiam os documentos servir à finalidade de uma escrita da história. (GUIMARÃES, 2011, p. 51) 
Documentos, arquivos, crítica e erudição formariam, de forma privilegiada, mais do que o léxico do historiador oitocentista, convertendo-se concretamente, na verdade, no elenco de virtudes epistêmicas da historiografia de base ocidental, pautando valorações, hierarquizações e discriminações. Munidas com esse patrimônio historiográfico, Maria de Lourdes Janotti e Maria Odila Dias tomaram seus homens de letras como dignos historiadores, a despeito do autodidatismo confessado deles.

Apesar de João Francisco Lisboa ter atuado como deputado na assembleia legislativa provincial do Maranhão, de ter sido político, militante, jornalista e até ficcionista, não deixou de ser definido como historiador. Para Janotti, seu sujeito de pesquisa pertenceria ao "mesmo 'sistema historiográfico' que abrange Joaquim Noberto Souza, Varnhagen e Pereira da Silva”, de maneira que o pertencimento destacado teria menos a ver com o fato dos indivíduos serem contemporâneos do que com a "preocupação com a documentação" (JANOTTI, 1971, p. 22-23). O uso documental foi tido como o fiel da balança. Nessa direção, a passagem a seguir, entremeando outras falas e historiadores, delineou umas das práticas usuais na definição da figura de saber em destaque:

Trabalhou também Lisboa no Conselho Ultramarino, demonstrando grande entusiasmo quanto às suas possibilidades. A esse respeito, escreve a Varnhagen: "sim senhor, tenciono enterrar-me de preferência na poeira desta repartição. Não duvido que neste arquivo se encontre a coleção mais completa e não explorada de documentos sobre o Brasil, desde 1753 até 1808, como não existe no Brasil, nem existirá jamais reunidos". (JANOTTI, 1971, p. 41) $)^{15}$

A poeira, signo por excelência da fase documental da operação historiográfica, conforme apontou Paul Ricoeur (RICOEUR, 2007, p. 178), foi destacada para demonstrar não só o árduo trabalho de pesquisa, mas fundamentalmente para qualificar a identidade intelectual deste tipo de trabalho. Ontem como hoje, enfrentar a poeira do arquivo funcionaria como uma espécie de batismo do(a) historiador(a). Lembrando a definição de Fustel de Coulanges,

\footnotetext{
${ }^{15}$ A citação de Lisboa aparece duas vezes na tese, o que indica sua importância na análise da
} autora. 
o historiador não é outro senão "o escavador de textos" antigos (HARTOG, 2017, p. 20).

Alentando o perfil do historiador, saiu-se em busca dos seus primeiros anos formativos, sobre o que se historicizou:

Sempre trabalhando só, como autodidata que era, preparou-se para exercer o mister de pesquisador nas poucas bibliotecas e arquivos de S. Luís. Evidentemente, há grandes diferenças entre o seu trabalho e o de Varnhagen, homem viajado, rico, diplomata, erudito e pesquisador incansável, mas não lhe faltam a necessária meditação sobre a interpretação dos documentos que teve em mãos e o exercício da crítica histórica. (JANOTTI, 1971, p. 252-253)

Junto com Gonçalves Dias, João Francisco Lisboa teria feito os primeiros levantamentos documentais dos arquivos de sua província, por volta dos anos 1830. Porém, se não foi um assíduo pesquisador de arquivos nacionais e internacionais, como Varnhagen, compartilharia certamente com este a erudição e a crítica histórica, portanto, o qualificativo de historiador.

Quanto à erudição, Maria de Lourdes Janotti destacou que seu sujeito de pesquisa não só leu autores gregos e romanos, como também escreveu sobre a dita Antiguidade Clássica. Nesse sentido, apontou-se os escritos do letrado sobre a democracia ateniense, a república e as instituições políticas romanas e as polis gregas. Versado em latim, teria se ocupado também de temas como "às eleições gregas, romanas, papais na Idade Média e às francesas e inglesas do século XIX. Torna-se bem evidente o seu aficionamento pelas leituras históricas" (JANOTTI, 1971, p. 72). A figura icônica de Napoleão Bonaparte também lhe teria ocupado durante um tempo. A valorização desse saber erudito fez Maria de Lourdes Janotti dedicar praticamente um capítulo inteiro de sua tese para discutir a visão de mundo de seu objeto, a respeito de temas variados, relacionados à política, economia e sociedade.

Acerca dessa faceta, apontou-se que o letrado maranhense não se limitava "a utilizar-se simplesmente da informação que o texto possa the dar; seu espírito possuía uma série de questões a propor ao documento, o que demonstra sua indiscutível sensibilidade histórica" (JANOTTI, 1971, p. 227). Segundo Herman Paul, uma das virtudes epistêmicas mais reivindicadas por uma 
concepção moderna de história, herdeira do século XIX historicista, diz respeito a um feeling particular, que levaria o seu portador a perceber questões importantes para a historiografia hodierna, como a diferença entre passado e presente, a especificidade de uma época ou de um acontecimento, a causalidade de um processo, a inter-relação entre fatos etc. (PAUL, 2011).

Na esteira dessas reflexões, João Ohara demonstrou como, dos letrados do IHGB aos profissionais universitários de fins do século XX, a sensibilidade histórica foi colocada como um atributo sine qua non do ofício do historiador no Brasil. A historiografia moderna não se forjou apenas enquanto o discurso da Razão, a expressão límpida e acabada desta, como poderia supor uma autoimagem disciplinar, cultivada e veiculada tanto no velho quanto no Novo Mundo. A escrita da história também mobilizaria sentimentos e emoções por parte dos historiadores e das historiadoras (OHARA, 2017; PAUL, 2011).

Maria de Lourdes Janotti não fez outra coisa senão arquitetar um historiador moderno. Eis as peças da construção:

Revela [o trabalho com a documentação], também, que não pretende repetir o mesmo tipo de história feita anteriormente: a crítica que faz [João Francisco Lisboa] aos cronistas é o rompimento definitivo com este gênero de história e demonstra estar inserido num 'sistema historiográfico' novo. Uma das características do trabalho de João Francisco Lisboa é a dúvida sistemática a que ele submete as informações que the é possível averiguar. (JANOTTI, 1971, p. 257)

Além da sensibilidade histórica, o letrado maranhense possuiria igualmente a prática cartesiana da dúvida sistemática, fundadora da ciência moderna, atitude iluminista de desconfiança da tradição, do que o passado legou para o presente. Até mesmo seu dito mestre, Varnhagen, teria sido objeto de suspeita, sendo diversas vezes corrigido, em razão de uma suposta desatenção em relação às fontes, segundo aquela autora.

Essa discussão feita pela historiadora, ex-assistente de Emília Viotti da Costa, estava profundamente articulada com a disciplina na qual sua pesquisa mantinha firmes laços. Pensar a documentação do sujeito examinado, a maneira como este trabalhou com as suas fontes, o uso feito do método histórico, era 
uma prática muito desenvolvida nos cursos de Teoria e Metodologia da História que Maria de Lourdes Janotti frequentou como estudante e depois atuou como professora-assistente. A professora com quem foi iniciada no magistério superior relembrou da seguinte maneira a docência na supracitada área curricular:

O curso era teórico e prático, com os alunos fazendo pesquisas no arquivo do Estado. Isso permitia analisar o uso e a crítica das fontes e discutir os problemas de sínteses históricas. [...] Fiz várias experiências durante o curso. Explorei as relações entre mito e historia, dei cursos de historiografia, discuti textos relacionados a teoria da historia, examinei as relações entre o historiador e a historia. (DA COSTA, 2002, p. 72-73)

Não à toa, o segundo maior tópico de sua tese, contendo 69 páginas, era um intitulado "Análise metodológica da obra", destinado justamente a comprovar e discutir a faceta historiográfica do exercício intelectual de João Francisco Lisboa. Para avalizar a importância dessa reflexão teórico-metodológica, registrese que o maior tópico, voltado para o exame da "visão política", foi feito em 77 laudas.

Em seu tratamento acerca de Robert Southey, por meio de History of Brazil, Maria Odila Dias forjou seu sujeito de pesquisa igualmente como um historiador, a despeito da fase inicial de poeta do letrado inglês ${ }^{16}$. Assim como João Francisco Lisboa, o personagem principal da historiadora da USP também seria um erudito, leitor voraz que leu sobre praticamente "todos os recantos da terra" (DIAS, 1972, p. 170). Sua obra principal sobre o Brasil traria "os mais variados dados sobre topografia, clima, vegetação e etnografia” (DIAS, 1972, p. 172). Segue a imagem do historiador erudito Robert Southey:

Como historiador, colhia dados nas coleções de Hakluyt, Ramusio, Purchas; criticava o descuido de Pinkerton ao elaborar a sua coleção de viagem. Seus longos poemas narrativos em torno de temas exóticos [...] eram laboriosamente documentados com fontes de viajantes. [...] Sábio de gabinete, era ávido destrinchador dos mapas de cartografia hipotética. [...] Elaboraria, com Arrowsmith e o capitão Burney, o primeiro mapa do interior do Brasil e da América do Sul (DIAS, 1972, p. 174)

\footnotetext{
${ }^{16}$ Ao longo da tese, frisa-se em vários momentos que Southey seria um "poeta frustrado", "poeta menor" e "poeta desprezado".
} 
O autor de History of Brazil evidenciaria um marca da historiografia oitocentista de base ocidental, conforme lembra Temistócles Cezar: a proximidade, beirando a quase indiferença, com a geografia ${ }^{17}$. Os saberes da Terra, físicos e humanos, mostrar-se-iam como fundamentais para a escrita da história, daí a necessidade de erudição. Não obstante, a geografia estava mesmo a serviço da história.

Com a sensibilidade de poeta servindo ao historiador, Maria Odila Dias sublinhou que

O historiador do Brasil enredou-se nos documentos com a intensidade de um convívio pessoal a ponto de saber com realismo pormenores sobre as mudanças de temperatura na Bahia e no Maranhã: "quando, no decurso de uma hora, todo o céu se carregava de nuvens e começava a chover torrencialmente”. [...] Em Keswick, no norte da Inglaterra, provaria o chá mate do Paraguai e teria em suas próprias mãos, folheando com familiaridade, livros impressos nas reduções jesuíticas. (DIAS, 1972, p. 373)

Diferentemente de Janotti, a autora de Robert Southey, historiador do Brasil entendeu que seu sujeito de pesquisa foi um historiador romântico cuja preocupação documental estaria a serviço não tanto de uma crítica, a esclarecer dúvidas e/ou corrigir possíveis equívocos, mas sim a funcionar como material que permitiria reviver o passado, quase presentificando-o para o(a) leitor(a), idealizado(a) como um(a) espectador(a).

As ideias a seguir comprovariam a concepção romântica do historiador do Brasil:

Escrever a história, tal como deve ser escrita, requer um poder de transmigração intelectual de que poucas pessoas são dotadas. Se o historiador quer tratar com justiça os indivíduos cujos atos registra, deve voltar à sua época e, pondo-se onde eles estiveram, tentar, enquanto possível, ver as cousas, como lhes pareciam aos seus próprios olhos, segundo a visão que tinham deles mesmos, à mesma luz, sob o mesmo ponto de vista e através dos mesmos recursos (DIAS, 1972, p. 376) ${ }^{18}$

\footnotetext{
17 O autor chega a apontar que a História Geral do Brasil, foi inicialmente pensada como o título de Geografia física do Brasil (CEZAR, 2018, p.28).

${ }^{18}$ As palavras, surgidas entre aspas (no início e no final do período), provavelmente são de Robert Southey, retiradas de algum texto deste, mas que Maria Odila Dias acabou não referenciando adequadamente.
} 
Analisando as palavras acima do letrado inglês, Dias teceu sua interpretação:

Este o motivo porque [Robert Southey] buscava principalmente os testemunhos diretos de cronistas e viajantes. [...] Daí porque não se cansava de ressaltar a importância das cartas e dos relatórios jesuíticos como documentação para a história da colonização ibérica na América do Sul. Referia-se com frequência ao sentido amplo em que concebia a história, chamando a atenção para a importância da análise crítica das pequenas anedotas, que forneceriam preciosos subsídios para a história social e mental de uma época. (DIAS, 1972, p. 376-377)

Ao contrário do João Francisco Lisboa de Maria de Lourdes Janotti, no Robert Southey da ex-assistente da cadeira de História da Civilização Brasileira, a documentação serviria menos para o estabelecimento de uma verdade histórica do que para um revival do passado. As fontes seriam como que fragmentos de um tempo ido, as quais, combinadas meticulosamente uma a uma, poderiam trazer um efeito de realidade, cabendo ao historiador ser o artífice dessa química.

No entanto, João Francisco Lisboa e Robert Southey compartilhariam o desejo de sentir o passado, de presentificar o tempo ido. Na reflexão sobre o historiador maranhense, a poeira emanada dos documentos preservados nos arquivos seria o elemento em torno do qual se poderia sorver o passado, enquanto que na discussão sobre o poeta inglês o pormenor, o fait divers já intuído por Roland Barthes (BARTHES, 1993), funcionaria como elemento de captura afetiva do vivido. Em um e outro, o passado emergiria sob o signo da experimentação, da sensibilidade, muito mais do que da mera e fria explicação racional. As historiadoras universitárias figuraram seus objetos com base em uma compreensão romântica de história, de acordo com a qual "o verdadeiro historiador deve descer aos mínimos pormenores, aproveitando em suas descrições fatos, anedotas e notícias quotidianas e diretas, desde que fossem extorquidos de fontes autênticas" (DIAS, 1972, p. 377) ${ }^{19}$.

\footnotetext{
19 Tais palavras não aparecem devidamente referenciadas (só contêm aspas no final do período), o que dificulta saber se elas foram proferidas pelo próprio Southey ou se fazem parte da interpretação mesmo da historiadora.
} 
O uso da categoria romântico para pensar a prática de historiadores, como destacou George Gusdorf, é relativamente comum em análises historiográficas que, do século XX, se voltaram para as épocas do XVIII e XIX (GUSDORF, 1993, p. 12-13). Christian Delacroix, François Dosse e Patrick Garcia, historicizando a historiografia francesa, apontaram o que chamaram de "questionamentos do modelo romântico", feito por historiadores metódicos responsáveis por institucionalizar a sua disciplina (DELACROIX et al., 2012, p. 70-71). Flávia Varella questionou recentemente a validade deste atributo para definir o empreendimento historiográfico de Robert Southey, optando por defini-lo a partir de um esforço de pesquisa documental e monumental do passado, próprios de uma historiografia que estava em um processo de cientificização (VARELLA, 2015).

Se o poeta inglês estava ou não ligado às tradições do romantismo, parece ser um dilema relacionado a uma visão unívoca do conceito, que não foca devidamente nos usos possíveis de tal categoria. O fato é que Maria Odila Dias, assim como Maria de Lourdes Janotti e outros historiadores e historiadoras do século passado, se valeram da categoria romântica para pensar e discutir a historiografia brasileira oitocentista, o que abre a possibilidade de se investigar o uso de tal noção, para além de sua confirmação ou negação. O esforço empreendido até então nestas linhas consiste justamente em interrogar tal uso, relacionando-o à construção de um passado disciplinar para a historiografia brasileira.

Assim, romântico, tal qual utilizado nas teses das historiadoras universitárias, apareceu para além de uma mera referência literária, ou de um estilo artístico. Antes, na narrativa historiográfica das historiadoras universitárias, para além da dimensão nacional já apontada, romântico tentou captar também aquilo que Márcia Regina Capelari Naxara qualificou de sensibilidade romântica, isto é, uma atitude afetiva e intelectual de camadas letradas do Ocidente oitocentista para com os vestígios do passado, por suas ruínas e fragmentos, encarados como verdadeiros monumentos do tempo pretérito (NAXARA, 2004, p. 231-293). Sob esses termos, as obras de João Francisco Lisboa e Robert Southey carregariam uma apreensão romântica do passado, orientadas que 
estariam pelo "verdadeiro prazer e deslumbramento produzido pelo contato com a pátina do tempo, com o cheiro do bolor, com o esverdeado do lodo" (ALBUQUERQU JR, 2019, p. 59) do mundo de antenho.

O fato de João Francisco Lisboa ter sido um historiador erudito, praticante da crítica documental, asseguraria, para Maria de Lourdes Janotti, sua modernidade, sua presença entre os historiadores nacionais modernos. Afinal, ser moderno é ser atual, contemporâneo. As virtudes epistêmicas que a historiadora universitária identificou em seu objeto (crítica das fontes, cruzamento documental, correção de autores, pesquisa em arquivos, sensibilidade histórica e percepção de causalidades, entre outras) justificariam a avaliação a seguir, em tom de consideração final: "sem dúvida alguma, João Francisco Lisboa não possuía uma concepção de historia muito distante da atual" (JANOTTI, 1971, p. 312)20. Do século XIX para as décadas finais da era seguinte, um historiador foi atualizado, modernamente. Com tal gesto de atualização, um passado disciplinar se conformava à historiografia brasileira.

Passado esse dominado por figuras masculinas que foram tanto nacionalizadas quanto disciplinarizadas. A nação e a disciplina da história do e no Brasil irmanaram-se, romanticamente, a partir da recuperação da obra intelectual de dois homens, um brasileiro e outro inglês. A história e a nação emergiram masculinamente, ainda que através de mãos femininas, as quais thes deram visibilidade. À nacionalização e disciplinarização da história parece corresponder também uma masculinização do saber em escrutínio, no que diz respeito ao seu passado. O elemento de gênero corrobora a importante tese da autora de The gender of history (SMITH, 2003): o passado "oficial" da historiografia de base ocidental mobiliza de forma hegemônica homens, resgatados sob a chancela metódica da disciplina, pretensamente assexuada.

A operação de disciplinarização - bem como a de nacionalização - de João Francisco Lisboa e Robert Southey não causam tanta estranheza, haja vista que insinuam um padrão de gênero comum nas historicizações da disciplina histórica,

\footnotetext{
${ }^{20}$ Quando da publicação do livro, a autora fez uma ligeira mas importante mudança na citação, deslocando o "não" para antes do advérbio "muito", ficando da seguinte maneira: "sem dúvida alguma, João Francisco Lisboa possuía uma concepção de historia não muito distante da atual" (JANOTTI, 1977, p. 191) [grifos nossos].
} 
conforme demonstração de Joan Scott (SCOTT, 1999). Assim como a nação possui seus homens ilustres, varões ilibados cultuados no altar da pátria, costuma ocorrer semelhantemente com a história, saber que zela e reverencia seus pais fundadores, seus precursores. Maria de Lourdes Janotti e Maria Odila Dias não escaparam de uma construção generificada do passado da historiografia que lhes antecedia, na medida em que atuaram no registro da disciplina, a qual supõe sempre limites e interditos, de acordo com as célebres lições de Michel Foucault em sua aula inaugural (FOUCAULT, 2012). Se a nação costuma obliterar as mulheres, vide o silenciamento feminino de diversas histórias nacionais (PERROT, 2017), a disciplina, uma vez historicizada por profissionais, pode também produzir o mesmo efeito.

Portanto, o passado da historiografia brasileira, modernizado através de letrados descritos como historiadores hábeis na crítica documental e na ressurreição de realidades históricas transcorridas, se aproximaria do presente, de modo a ter com esse tempo relações de continuidade. Nas teses analisadas, o passado disciplinar não foi arcaizado, isto é, apartado nem tampouco rejeitado do tempo vigente. Nesta temporalidade, haveria espaço para ele. Menos alteridade do que mesmidade, ele foi ficcionado para não causar tanta estranheza, já que as práticas intelectuais, realizadas pelos dois letrados ligados a tal passado, provocariam reconhecimento por parte dos historiadores e das historiadoras universitários.

Do passado disciplinar romântico para o presente de Janotti e Dias, do século XIX para a realidade do início dos anos 1970, haveria como que um laço, um elo unindo temporalidades cronologicamente distintas, porém interligadas, jamais heterocronias extremadas. A temporalização da historiografia brasileira indicaria, pois, uma linearidade, um atravessamento ao longo das eras. O tempo linear e contínuo, próprio da modernidade, dominaria a história do e no Brasil. Tempo senhor, que não admite desvios e incorreções, tal qual o masculino, a historiografia brasileira teria nascido menos por ruptura do que por continuidade. Seu passado disciplinar seria imagem e semelhança de seu presente.

Assim, a positivação das figuras de João Francisco Lisboa e Robert Southey enquanto "mestres do ofício", bem como a boa acolhida dos trabalhos de Maria 
de Lourdes Janotti e de Maria Odila Dias ${ }^{21}$, foram sinais de uma cumplicidade em torno do passado romântico da historiografia brasileira. Menos renegado do que afirmado, ele foi pincelado como ponto de relevo na paisagem de evolução dos estudos históricos no Brasil; seria o momento de nascimento de uma historiografia praticada em bases documentais, metodicamente, devidamente crítica. Os procedimentos de pesquisa - consulta aos arquivos, seleção, leitura e exame das fontes - atestariam uma proximidade com tal passado, esculpido não tanto como diferença quanto como semelhança. Colonizando o passado a partir do signo da crítica documental, enxergando-o como moderno, forjou-se uma herança a se reivindicar, afirmada em um presente que visava consolidar uma historiografia profissional, universitária, vista também como crítica.

Foi este presente de profissionalização, de fortalecimento da disciplina em bases científicas, metódicas, que positivou o passado oitocentista, tal qual poderia ser visto nas obras de João Francisco Lisboa e Robert Southey. Por mais que, desde a segunda metade do século anterior, historiadores e historiadoras no Brasil tendessem a enfatizar os traços amadores, tradicionais e conservadores dos letrados da era oitocentista (LAPA, 1976, p. 190-194), o elogio de Janotti e Dias são menos pessoais do que disciplinares, isto é, direcionam-se aos fundamentos epistemológicos da disciplina histórica. Ao se situarem no registro da disciplina, elas teceram méritos não individuais de seus sujeitos de pesquisa, mas sim coletivos, próprios de uma comunidade de saber específica. O método histórico, a crítica das fontes, a dúvida cartesiana, a volúpia historicista de perceber o passado em seus termos, seriam os protocolos da história, do conhecimento histórico que teriam sido praticados por João Francisco Lisboa e Robert Southey.

O passado romântico da historiografia brasileira espelhava o seu próprio presente, no qual a Universidade despontava como esfera privilegiada da produção historiadora, processo fortemente em curso sob a batuta de um regime autoritário que expandia a pós-graduação no país, junto com uma maior oferta de universidades e de cursos superiores (PEREZ, 2018). Tudo isso gerava uma maior ampliação da historiografia no país, o que permitia o seu fortalecimento,

\footnotetext{
${ }^{21}$ Percorrendo os exemplares do jornal A Folha de São Paulo da década de 1970, é possível encontrar resenhas elogiosas dos livros de Maria de Lourdes Janotti e de Maria Odila Dias, escritas tanto por jornalistas como por historiadores.
} 
ainda que sob o duro preço da censura e da perseguição política. O tempo vivido era de ação, de projetos, de enfrentamentos nas mais variadas dimensões da sociedade. Em uma palavra: de engajamento. Daí tanto se falar em reforma, desenvolvimento, modernização, inovação, palavras comuns no reportório do governo discricionário militar inaugurado em 1964 (ALVES, 2005).

Se possibilidades se colocavam para as instituições e para os indivíduos, Maria de Lourdes Janotti e Maria Odila Dias avançaram não só em direção ao passado, historicizando disciplinarmente a história, como se engajaram no presente, contribuindo com a pesquisa histórica, cerrando-a no espaço universitário que então se expandia e se consolidava. Logo, foram sujeitos da história, tanto quanto artesãs da disciplina. Suas teses, mesmo fabricando um passador romântico oitocentista, não se afastaram do presente vivido, assim como não perderam de vista o futuro esperado. Os trabalhos que realizaram não deixaram de mirar o desenvolvimento da disciplina, da área de conhecimento em que atuavam, conforme se pode entrever com base nas palavras convidativas a seguir:

A historiografia brasileira tem sido insuficientemente estudada. A pobreza do número e do conteúdo de obras que se ocupam de tal matéria revela um campo ainda inexplorado, que aguarda investigação metódica. Ela tem sido tratada por dois tipos de obras: as histórias da literatura e os estudos isolados sobre historiadores. Estes tipos de trabalho se caracterizam por uma completa assistematização processual. [...] Deve-se aspirar a uma história da historiografia com problemas historiográficos. (JANOTTI, 1972, p. 10)

E aqui, rompendo "os sons do silêncio", bem analisado e denunciado por Maria da Gloria de Oliveira (OLIVEIRA, 2018), evidencia-se o papel de duas historiadoras universitárias engajadas disciplinarmente numa área de saber frequentemente contada e narrada por homens, sejam os do passado ou os do presente. 


\section{Referências}

ALBUQUERQUE JÚNIOR, Durval Muniz.A poética do arquivo./n: O tecelão dos tempos. São Paulo: Intermeios, 2019.

ALBUQUERQUE JÚNIOR. A hora da estrela: história e literatura, uma questão de gênero? In: História: a arte de inventar o passado. São Paulo: EDUSC, 2007.

ALVES, Maria Helena Moreira. Estado e oposição no Brasil (1964-1984). Bauru: SP, Edusc, 2005.

ARAÚJO, Valdei Lopes de. O século XIX no contexto da redemocratização brasileira. In: ARAÚJO, Valdei Lopes de; OLIVEIRA, Maria da Gloria de (Org.).

Disputas pelo passado: História e historiadores do império do Brasil. Ouro Preto: Edufop/PPGHIS, 2012.

BARTHES, Roland. Mitologias. Rio de Janeiro: Bertrand Brasil, 1993.

BASSETTO, Sylvia. Entrevista com Emília Viotti da Costa. São Paulo, Revista da Adusp, 1999.

BLAY, Eva Alterman; LANG, Alice Beatriz da S. G. (Org.). Mulheres na USP: horizontes que se abrem. São Paulo: Humanitas, 2004.

BURMESTER, Maria Oliveira. A (des)construção do discurso histórico: a historiografia brasileira dos anos 1970. Curitiba: Aos quatro ventos, 1998.

BUTLER, Judith. "Variações sobre sexo e gênero: Beauvoir, Wittig e Foucault" In: BENHABIB, Seyla \& CORNELL, Drucilla. Feminismo como crítica da modernidade. Rio de Janeiro: Editora Rosa dos Tempos, 1987.

BOURDIEU, Pierra. Homo academicus. Florianópolis: Editora da UFSC, 2011.

CANDIDO, Antônio. Formação da literatura brasileira: momentos decisivos. Belo Horizonte: Itatiaia, 1981.

CERTEAU, Michel de. História e psicanálise: entre ciência e ficção. Belo Horizonte: Autêntica, 2011.

CEZAR, Temistocles. Ser historiador no século XIX: o caso Varnhagen. Belo Horizonte: Autêntica, 2018.

COSTA, Emília Viotti da. Entrevista. In: COSTA, Emília Viotti da. Brasil: história, textos e contextos. São Paulo: UNESP, 2015. 
COSTA, Emília Viotti da. Anais do I seminário de estudos brasileiros. São Paulo: IEB, 1972, Vol II.

COSTA, Emília Viotti da. Entrevista. In: MORAES, José Geraldo Vinci de \& REGO, José Marcio (Entrevistadores). Conversas com historiadores brasileiros. São Paulo: Ed. 34, 2002.

CROCE, Benedetto. História e crônica. In: GARDINER, Patrick. Teorias da história. Lisboa: Fundação Calouste, 1984.

DELACROIX, Christian; DOSSE, François; GARCIA, Patrick. As corrente históricas na França: séculos XIX e XX. Rio de Janeiro: Editora FGV, 2012.

DIAS, Maria Odila Leita da Silva. Robert Southey, historiador do Brasil- o fardo do homem branco na Inglaterra Pré-Vitoriana e a formação da nacionalidade brasileira. Tese de doutoramento apresentada ao departamento de história da Faculdade de Filosofia, Letras e Ciências Humanas da Universidade de São Paulo, São Paulo, 1972.

DIAS, Maria Odila Leita da Silva. O fardo do homem branco: Robert Southey, historiador do Brasil. Rio de Janeiro: Companhia da Editora Nacional, 1974.

DIAS, Maria Odila Leita da Silva. Discurso da homenageada. Outorga do título de professora Emérita da Faculdade de Filosofia, Letras e Ciências Humanas da Universidade de São Paulo, 2013. Texto sem paginação.

DIAS, Maria Odila Leita da Silva. Entrevista. In: MORAES, José Geraldo Vinci de \& REGO, José Marcio (Entrevistadores). Conversas com historiadores brasileiros. São Paulo: Ed. 34, 2002.

DA SILVA, Rogério Forastieri. História da historiografia. Bauru, SP: EDUSC, 2001.

ERBERELI JÚNIOR, Otávio. A trajetória intelectual de Alice Piffer Canabrava: um ofício como sacerdócio (1935-1997). Tese de doutorado apresentada a Faculdade de Filosofia, Letras e Ciências Humanas da Universidade de São Paulo, 2019.

FICO, Carlos. Versões e controvérsias sobre 1964 e a ditadura militar Rev. Bras. Hist., 2004, vol.24, n.47, pp.29-60.

FIGUEIRA, Pedro de Alcântara. Historiografia brasileira: 1900-1930 (análise crítica). Tese de doutoramento. Faculdade de Filosofia, Ciências e Letras de Assis - São Paulo, 1974. 
FOUCAULT, Michel. A ordem do discurso. Petrópolis: Loyola, 2012.

GONTIJO, Rebeca. Revisão e prospecção da historiografia no Brasil nos anos 1970. In: BENTIVOGLIO, Julio; NASCIMENTO, Bruno César (Org.). Escrever história. Serra: Editora Milfontes, 2017.

GUIMARÃES, Manoel Salgado. História e erudição. In: NICOLAZZI, Fernanda; MOLLO, Helena Miranda; ARAÚJO, Valdei Lopes de. Aprender com a história?O passado e o futuro de uma questão. Rio de Janeiro: FGV, 2011.

GUIMARÃES, Manoel Salgado. Historiografia e cultura histórica: notas para um debate. Ágora, Santa Cruz do Sul, v.11, n.1. p. 31-47, jan./jun. 2005.

GUSDORG, George. Le romantisme I: le savoir romantique. Paris, 1993.

HARTOG, François. Evidências da história: o que os historiadores veem. Belo Horizonte: Autêntica, 2017.

HUIZINGA, Johan. Homo Ludens. São Paulo: Perspectiva, 2008.

JANOTTI, Maria de Lourdes Monaco. João Francisco Lisboa: contribuição para o estudo da historiografia brasileira. Tese de doutoramento apresentada ao departamento de história da Faculdade de Filosofia, Letras e Ciências Humanas da Universidade de São Paulo, São Paulo, 1971.

. Discurso da homenageada. Outorga do título de professora Emérita da Faculdade de Filosofia, Letras e Ciências Humanas da Universidade de São Paulo, 2014. Texto sem paginação.

KELLEY, Donald R. History and the disciplines. New York: University of Rochester Press, USA, 1997.

LAPA, José Roberto do Amaral. A história em questão: historiografia brasileira contemporânea. Petrópolis: Vozes, 1976.

LIBLIK, Carmen Silvia da Fonseca Kummer. Uma história toda sua: trajetórias de historiadoras brasileiras (1934-1990). Tese de doutorado apresentada ao programa de Pós-Graduação em História da Universidade Federal do Paraná, 2017.

LIMA, Aryana Costa. De um curso d’agua a outro: memória e disciplinarização do saber histórico na formação dos primeiros professores no curso de história da USP. Tese apresentada ao Programa de Pós-Graduação em História Social do Instituto de História da Universidade Federal do Rio de Janeiro, Rio de Janeiro, 2018. 
LIMA, Luiz Costa. Os destinos da subjetividade: história e natureza no romantismo. In: LIMA, Luiz Costa. Trilogia do controle. Rio de Janeiro: Topbooks, 2007.

LOWY, Michael; SAYRE, Robert. Romantismo e melancolia. Petrópolis: Vozes, 1995.

\section{LOWY, Michael; SAYRE, Robert. As Aventuras de Karl Marx contra o Barão de} Münchhausen. São Paulo: Cortez, 1994.

MOTTA, Rodrigo Pato de Sá. As universidades e o regime militar: cultura política brasileira e modernização autoritária. Rio de Janeiro: Zahar, 2014.

NAXARA, Márcia R. C. Cientificismo e sensibilidade romântica: em busca de um sentido explicativo para o Brasil do século XIX. Brasília: UNB, 2004.

ODÁLIA, Nilo. As formas do mesmo: ensaios sobre o pensamento historiográfico de Varnhagen e Oliveira Viana. São Paulo: Editora da UNESP, 1997.

OHARA, João Rodolfo Munhoz. Virtudes epistêmicas na historiografia brasileira (1980-1990). Tese de Doutorado apresentada à Faculdade de Ciências e Letras de Assis - UNESP, São Paulo, 2017.

OLIVEIRA, Maria da G. de. Os sons do silêncio: interpelações feministas decoloniais à História da historiografia. História da Historiografia: International Journal of Theory and History of Historiography, v. 11, n. 28, 8 dez. 2018.

PAUL, Herman. self-images of the historical profession: idealized pratics and myths of origin. Storia della Storiografia, Num. 59-60, 2011, p. 157-170.

PAUL, Herman. Perfoming history: how historical scholarship is shaped by epistemic values. History and Theory, Vol. 50, Num. 01, 2011, p.1-19.

PEREZ, Rodrigo. O engajamento político e historiográfico no ofício dos historiadores brasileiros: uma reflexão sobre a fundação da historiografia brasileira contemporânea (1975-1979). História da Historiografia, n. 26, jan-abri, ano 2018, 197-222.

PERROT, Michelle. Os excluídos da história: operários, mulheres e prisioneiros. Rio de Janeiro: Paz e Terra, 2017.

MOTTA, Rodrigo Pato Sá. As universidades e o regime militar: cultura política brasileira e modernização autoritária. Rio de Janeiro: Zahar, 2014.

PIERRE, Bourdieu. A dominação masculina. Rio de Janeiro: Bertrand Brasil, 2005. 
RANCIĖRE, Jacque. Políticas da escrita. Rio de Janeiro: Editora 34, 1995.

REIS, Daniel Aarão. Ditadura militar, esquerdas e sociedade. Rio de Janeiro: ZAHAR, 2005.

Revista de história, Num. 85, 10 trimestre, São Paulo, 1971.

Revista de história, Num. 100, Vol. 84, São Paulo, 1974.

RICOEUR, Paul. A memória, a história e o esquecimento. Campinas, São Paulo: Unicamp, 2007.

SCOTT, Joan Wallach. Gênero: uma categoria útil de análise histórica. Educação \& Realidade. Porto Alegre, vol. 20, no 2, jul./dez. 1995, pp. 71-99.

SCOTT, Joan Wallach. Gender and the politics of history. New York: Columbia University Press, 1999.

SECOM UNB. Um convite para filosofar. Entrevista publicada em 13/09/2018. Disponível em: https://noticias.unb.br/publicacoes/112-extensao-ecomunidade/2481-um-convite-para-filosofar acesso em 06/03/2020.

VARELLA, Flávia Florentino. Reunindo o passado: contextos discursivos e linguagens historiográficas na History of Brazil de Robert Southey. Tese de doutorado apresentada ao programa de pós-graduação em história da Universidade Federal do Rio Grande do Sul, Porto Alegre, 2015.

ZIMMERMANN, B.; WERNER, M. Pensar a história cruzada: entre empiria e reflexividade. Texto de história, Vol. 11, Num. 1-2, 2003. 